\title{
DAMPAK PENINGKATAN KENDARAAN BERMOTOR TERHADAP TINGKAT KECELAKAAN DI KOTA PALOPO
}

\author{
Natser Istiqlal Chalid ${ }^{1)}$ \\ ${ }^{1)}$ Dosen Fakultas Teknik Universitas Sulawesi Barat \\ 1) natser.chalid@yahoo.com
}

\begin{abstract}
Abstrak
Meningkatnya kepemilikan kendaraan tentunya akan mempengaruhi kepadatan jalan raya terutama di Kota Palopo. Kemacetan dan kecelakaan lalu lintas adalah hal yang sulit dipisahkan akibat bertambahnya tingkat kepemilikan kendaraan dan jumlah korban yang tidak bisa dibilang sedikit memberikan dampak yang cukup besar. Penelitian dan pengambilan data dilakukan di Kota Palopo sulawesi Selatan. Objek utama studi penelitian ini adalah pihak kepolisain Porles Kota Palopo (Lakalantas) dan Kantor Samsat Kota Palopo. Waktu penelitian mencakup pengambilan data sampai dengan pengelolaannya dilaksanakan selama 7 bulan, yaitu pada bulan Februari sampai dengan bulan Agustus 2016. Dari hasil analisis data dan pembahasan yang telah dilakukan menggunakan analisa metode Aritmatik, untuk mengetahui laju pertumbuhan kendaraan dan menentukan korelasi antara tingkat kasus kecelakaan yang ada di Kota Palopo serta menentukan tingkat presentase pertumbuhan kendaran dan tingkat kasus kecelakaan dalam tiap tahunnya, maka dapat disimpulkan bahwa: (1) Laju pertumbuhan kendaraan bermotor di Kota Palopo pada tahun 2021 sebesar $2.0 \%$. Peningkatan ini mengalami kenaikan setiap tahun dikarenakan semakin meningkatnya kebutuhan kepemilikan kendaraan bermotor; dan (2) Korelasi antara bertambahnya jumlah kendaraan di Kota Palopo, berdampak pada jumlah kasus kecelakaan yang terjadi, ini dapat di lihat dari hasil analisa gambar grafik korelasi antara tingkat pertumbuhan kendaraan dan tingkat kasus kecelakaan. Peningkatan jumlah kendaraan pada tahun 2017 adalah $2.2 \%$ sedangkan jumlah kecelakaan juga mengalami kenaikan sebesar $42.3 \%$.
\end{abstract}

Kata Kunci: Kecelakaan Lalu Lintas, Kendaraan Bermotor dan Metode Aritmatik

\section{PENDAHULUAN}

Salah satu permasalahan dalam transportasi adalah kecelakaan lalu lintas, maka penelitian kecelakaan lalulintas yang berbasis lokal sangat penting karena transportasi mempunyai peran strategis dalam mendukung pembangunan dan integrasi sebagai bagian dari upaya memajukan kesejahteraan umum sebagaimana diamanatkan dalam Pembukaan Undang Dasar Negara Republik Indonesia Tahun 1945. Pertumbuhan ekonomi dan jumlah penduduk yang besar menyebabkan meningkatnya aktivitas kebutuhan yang tentunya meningkatkan pula kebutuhan akan alat transportasi, baik itu pribadi maupun umum. Dengan kondisi angkutan umum yang kurang memadai, masyarakat mengatasinya dengan menggunakan kendaraan pribadi semakin meningkat pula, baik itu kepemilikan roda empat maupun roda dua. Pemakaian kendaraan pribadi di satu pihak akan menguntungkan, akan tetapi di pihak lain akan menimbulkan masalah lalu lintas (Tamin, 2000). Permasalahan lalu lintas yang dihadapi salah satunya adalah kecelakaan lalu lintas.

Kota Palopo adalah kota yang memiliki penduduk cukup banyak dimana terus mengalami perubahan dan perkembangan cukup pesat. Kota Palopo tidak hanya sebagai pusat pemerintahan, akan tetapi juga tumbuh dan berkembang sebagai pusat perekonomian. Adanya pertambahan penduduk dan taraf hidup masyarakat yang semakin meningkat, didukung dengan kebutuhan manusia yang melibatkan kepemilikan kendaraan pribadi semakin meningkat pula. Populasi dan tingkat kepemilikan kendaraan di Palopo dalam beberapa tahun terakhir ini terus tumbuh dengan cepat. 
Menurut (Soehartono, 1990). Keseimbangan antara pengemudi, kemajuan teknologi kendaraan dan penyedia prasarana lalu lintas merupakan tiga kombinasi yang menentukan mobilitas transportasi. Jika salah satu unsur tersebut tertinggal dalam adaptasinya maka akan terjadi kesenjangan yang akan menjurus kepada terjadinya kecelakaan. Kecelakaan lalu lintas yang merupakan salah satu permasalahan dari dampak yang terjadi karna adanya mobilitas transportasi yang semakin meningkat.

Meningkatnya kepemilikan kendaraan tentunya akan mempengaruhi kepadatan jalan raya terutama di Kota Palopo. Kemacetan dan kecelakaan lalu lintas adalah hal yang sulit dipisahkan akibat bertambahnya tingkat kepemilikan kendaraan dan jumlah korban yang tidak bisa dibilang sedikit memberikan dampak yang cukup besar. Semakin banyaknya Peningkatan kendaraan bermotor yang kian bertambah tiap tahunnya tentunya sangat mengkhawatirkan karena tidak seimbangnya dengan bertambahnya marka jalan atau sarana dan prasarana jalan. Hal ini diperburuk lagi dengan meningkatnya pengandara yang berasal dari hampir semua kelompok umur, dari anak-anak hingga orang dewasa tanpa dibarangi dengan pengetahuan dan kematangan berkendara dijalan raya.

Berdasarkan permasalahan tersebut di atas, maka penulis tertarik untuk melakukan penelitian dengan judul "Dampak Peningkatan Kendaraan BERMOTOR Terhadap Tingkat Kecelakaan di Kota Palopo".

\section{METODOLOGI PENELITIAN}

Metode Deskriptif Kuantitatif (mendeskripsikan), yaitu penelitian yang bertujuan menjelaskan fenomena yang ada dengan menggunakan angka-angka untuk mencandarkan karakteristik individu atau kelompok (Syamsudin \& Damiyanti: 2011). metode yang digunakan untuk mencari unsur-unsur, ciri-ciri, sifat-sifat suatu fenomena. Metode ini dimulai dengan mengumpulkan data, menganalisis data dan menginterprestasikannya. Metode deskriptif dalam pelaksanaannya dilakukan melalui: teknik survey, studi kasus, studi tentang waktu dan gerak, analisis tingkah laku, dan analisis dokumenter. Penelitian dan pengambilan data dilakukan di Kota Palopo, sulawesi Selatan. Objek utama studi penelitian ini adalah pihak kepolisain Porles Kota Palopo (Lakalantas) dan Kantor Samsat Kota Palopo. Waktu penelitian mencakup pengambilan data sampai dengan pengelolaannya dilaksanakan selama 7 bulan, yaitu pada bulan Februari sampai dengan bulan Agustus 2017. Pada 14 februari, peneliti mengambil data eksisting kepolisain Porles Kota Palopo (Lakalantas) dan Kantor Samsat Kota Palopo.

Data - data yang digunakan dalam penelitian ini meliputi data primer dan data sekunder Yaitu: (1) Data primer pada penelitian ini : ukuran jalan yang dilakukan oleh pengamat, keadaan jalan raya, kendaraan yang lalu lalang pada waktu tertentu, data-data kecelakaan yang diambil, dan informasi-informasi lain yang di anggap membantu dalam penyusunan skripsi ini; (2) Data sekunder merupakan data tambahan yang diperlukan untuk melengkapi bahan penulisan misalnya buku-buku literature, website internet yang dirasa dapat mendukung dalam penelitian ini.

\section{HASIL DAN PEMBAHASAN}

Secara geografis Kota Palopo berada pada koordinat 2 ${ }^{\circ} 53^{\prime} 15^{\prime \prime}$ - 304'08"

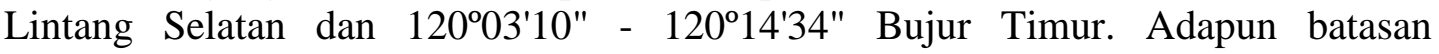
administrasi Kota Palopo terdiri dari: (1) Sebelah Utara berbatasan dengan 
Kecamatan Walenrang Kabupaten Luwu; (2) Sebelah Selatan berbatasan dengan Kecamatam Bua Kabupaten Luwu; (3) Sebelah Timur berbatasan dengan Teluk Bone dan (4) Sebelah Barat berbatasan dengan Kecamatan Tondon Nanggala Kabupaten Toraja Utara. Kota Palopo merupakan salah satu wilayah kota administrasi yang berada didalam wilayah Provinsi Sulawesi Selatan dengan luas wilayah 258,17 $\mathrm{Km}^{2}$ dengan 9 (Sembilan) wilayah administrasi kecamatan yang meliputi Kecamatan Wara Selatan, Kecamatan Sendana, Kecamatan Wara, Kecamatan Wara Timur, Kecamatan Mungkajang, Kecamatan Wara Utara, Kecamatan Bara, Kecamatan Telluwanua dan Kecamatan Wara Barat.

Berikut ini adalah data jumlah kasus tingkat kecelakaan Lalu Lintas yang di ambil dari Lakalantas Polres Kota Palopo 5 Tahun terakhir mulai dari Tahun 2012 hingga Tahun 2016.

Tabel 1. Data jumlah kasus kecelakaan

\begin{tabular}{lcc}
\hline \hline NO & TAHUN & JUMLAH KASUS \\
\hline \hline & & \\
\hline 1 & 2012 & 98 \\
2 & 2013 & 104 \\
3 & 2014 & 228 \\
4 & 2015 & 647 \\
5 & 2016 & 304 \\
\hline & JUMLAH & $\mathbf{1 3 8 1}$ \\
\hline \hline
\end{tabular}

Sumber : Polres Kota Palopo

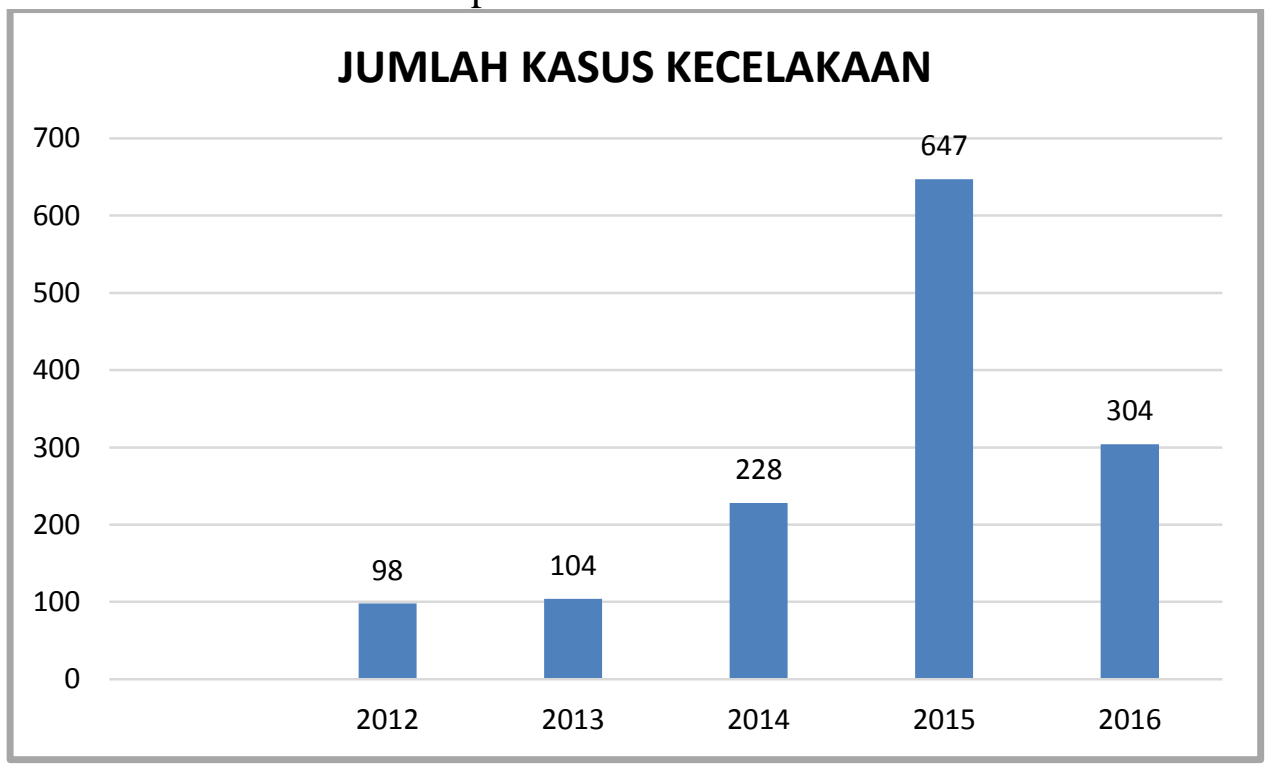

Gambar 1. Grafik Jumlah Kasus Kecelakaan di Kota Palopo

Dari data kasus jumlah kecelakaan yang ada di kota Palopo di hitung dari 5 tahun terakhir pada tahun 2012 sebanyak 98 kasus, 2013 sebanyak 104 kasus, 2014 sebanyak 228 kasus, 2015 sebanyak 647 dan 2016 sebanyak 304 kasus kecelakaan yang ada di kota palopo. 
Berikut ini adalah data jumlah tingkat kendaraan yang di ambil dari Kantor Samsat Kota Palopo 5 Tahun terakhir mulai dari Tahun 2012 hingga Tahun 2016.

Tabel 2. Data jumlah kendaraan

\begin{tabular}{ccc}
\hline \hline NO & TAHUN & JUMLAH KENDARAAN \\
\hline 1 & 2012 & 34098 \\
2 & 2013 & 34014 \\
3 & 2014 & 35886 \\
4 & 2015 & 34761 \\
5 & 2016 & 34818 \\
\hline & JUMLAH & $\mathbf{1 7 3 5 7 7}$ \\
\hline \hline
\end{tabular}

Sumber : Samsat Kota Palopo

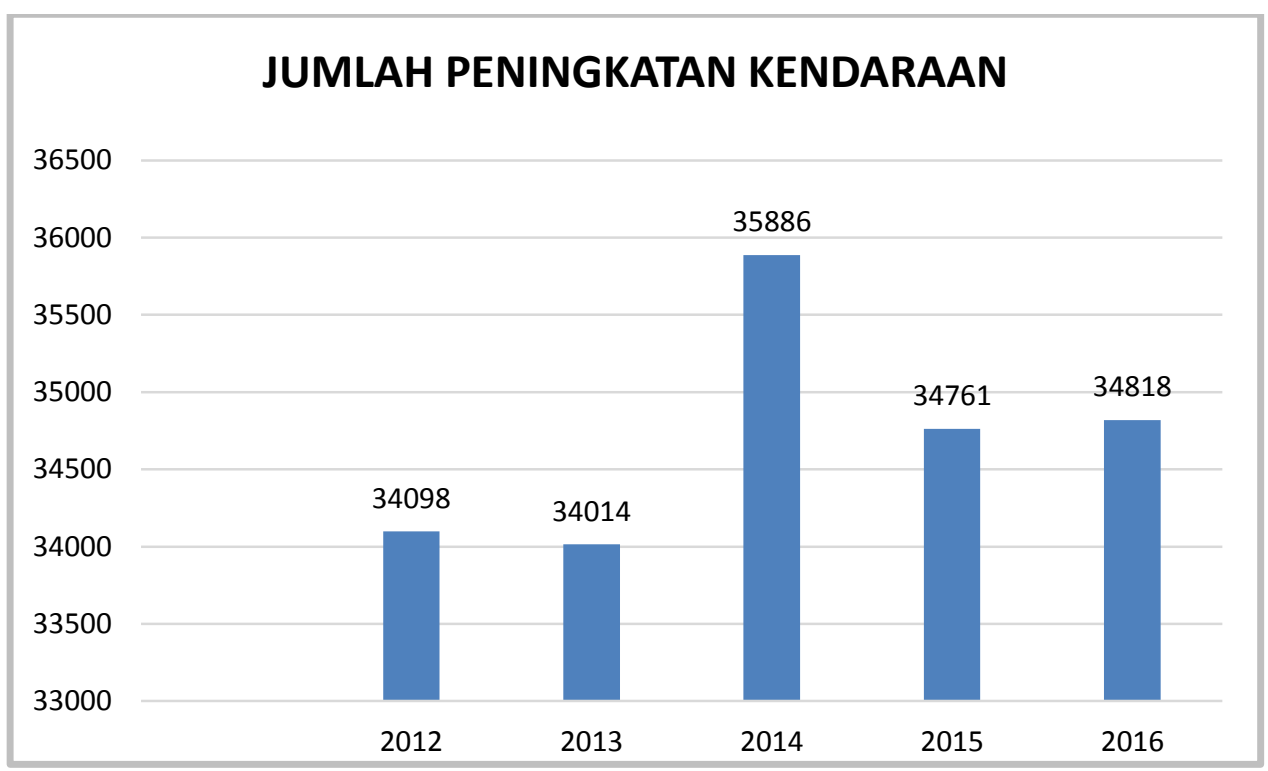

Gambar 2. Grafik Jumlah Peningkatan Kendaraan di Kota Palopo

Jumlah peningkatan jumlah kendaraan 5 tahun terakhir di Kota Palopo pada tahun 2012 sebanyak 34098 unit, 2013 sebanyak 34014 unit, 2014 sebanyak 35886 unit, 2015 sebanyak 34761 unit dan 2016 sebanyak 34818 unit. Perhitungan dari Metode Aritmatik adalah sebagai berikut:

Dimana:

$$
A=P o+\mathrm{n} \cdot \mathrm{r} \Rightarrow s r^{\prime}=\frac{(\mathrm{P}-\mathrm{n})}{\mathrm{n}}
$$

Sr' = Jumlah kendaraan/jumlah kasus Tahun terakhir

Po = Jumlah kendaraan/jumlah kasus pada (awal tahun) tahun ke - 0

$\mathrm{r} \quad=$ Pertumbuhan kendaraan/jumlah kaus dalam 1 tahun

$\mathrm{n}=$ Jumlah tahun/banyak tahun penelitian

Mencari nilai rata-rata jumlah kendaraan di kota palopo dapat dihitung dengan:

Dimana :

$$
r^{1}=P n-P o
$$

Pn = Jumlah kendaraan/jumlah kasus yang diproyeksikan tahun ke-n

Po $\quad=$ Jumlah kendaraan/jumlah kasus pada (awal tahun) tahun 
ke -1

$\mathrm{r}^{1}=$ Pertumbuhan kendaraan/jumlah kasus dalam 1 tahun

Maka digunakan perhitungan:

$\mathrm{r}^{1}=$ Jumlah kendaraan pada tahun 2013 - jumlah kasus pada tahun 2012

$\mathrm{r}^{1} \quad=\quad 34098-34014$

$\mathrm{r}^{1} \quad=84$

Maka diperoleh hasil Perhitungan untuk rata-rata jumlah kendaraan tahun 2012 sampai dengan tahun 2016.

Tabel 3. Hasil perhitungan rata-rata jumlah kendaraan tiap tahun \& (\%)

\begin{tabular}{cccc}
\hline \hline Tahun & Jumlah Pertumbuhan Kendaraan & $\mathbf{r}^{\prime}$ & Presentase (\%) \\
\hline 2012 & 34098 & 84 & $-0.2 \%$ \\
2013 & 34014 & 1872 & $5.2 \%$ \\
2014 & 35886 & 1125 & $-3.2 \%$ \\
2015 & 34761 & 57 & $0.2 \%$ \\
2016 & 34818 & & \\
\hline & Jumlah & 3138 & \\
\hline \hline
\end{tabular}

Sumber : Hasil Analisa

$$
\begin{aligned}
& r=\frac{\mathrm{Sr}^{1}}{\mathrm{n}} \\
& x=\frac{3138}{4} \\
& r=785
\end{aligned}
$$

Perhitungan Metode Aritmatik untuk jumlah kendaraan rata-rata dengan menggunakan tahun 2016 adalah:

$$
\begin{aligned}
\text { Pn } & =\text { Po }+\mathrm{n} \cdot \mathrm{r} \\
& =34818+(1 \times 785) \\
& =35603
\end{aligned}
$$

Maka diperoleh hasil Perhitungan dengan metode aritmatik untuk jumlah kendaraan tiap tahunnya di Kota Palopo, dari tahun 2016 sampai dengan tahun 2021.

Tabel 4. Hasil Peramalan dari Perhitungan metode aritmatik untuk jumlah kendaraan di Kota Palopo.

\begin{tabular}{ccccc}
\hline \hline No & Tahun & $\mathbf{r}^{\prime}$ & Pn & Presentase (\%) \\
\hline 1 & 2017 & 785 & 35603 & $2.2 \%$ \\
2 & 2018 & 785 & 36388 & $2.2 \%$ \\
3 & 2019 & 785 & 37173 & $2.1 \%$ \\
4 & 2020 & 785 & 37958 & $2.1 \%$ \\
5 & 2021 & 785 & 38743 & $2.0 \%$ \\
\hline \hline
\end{tabular}

Sumber: Hasil Analisa 


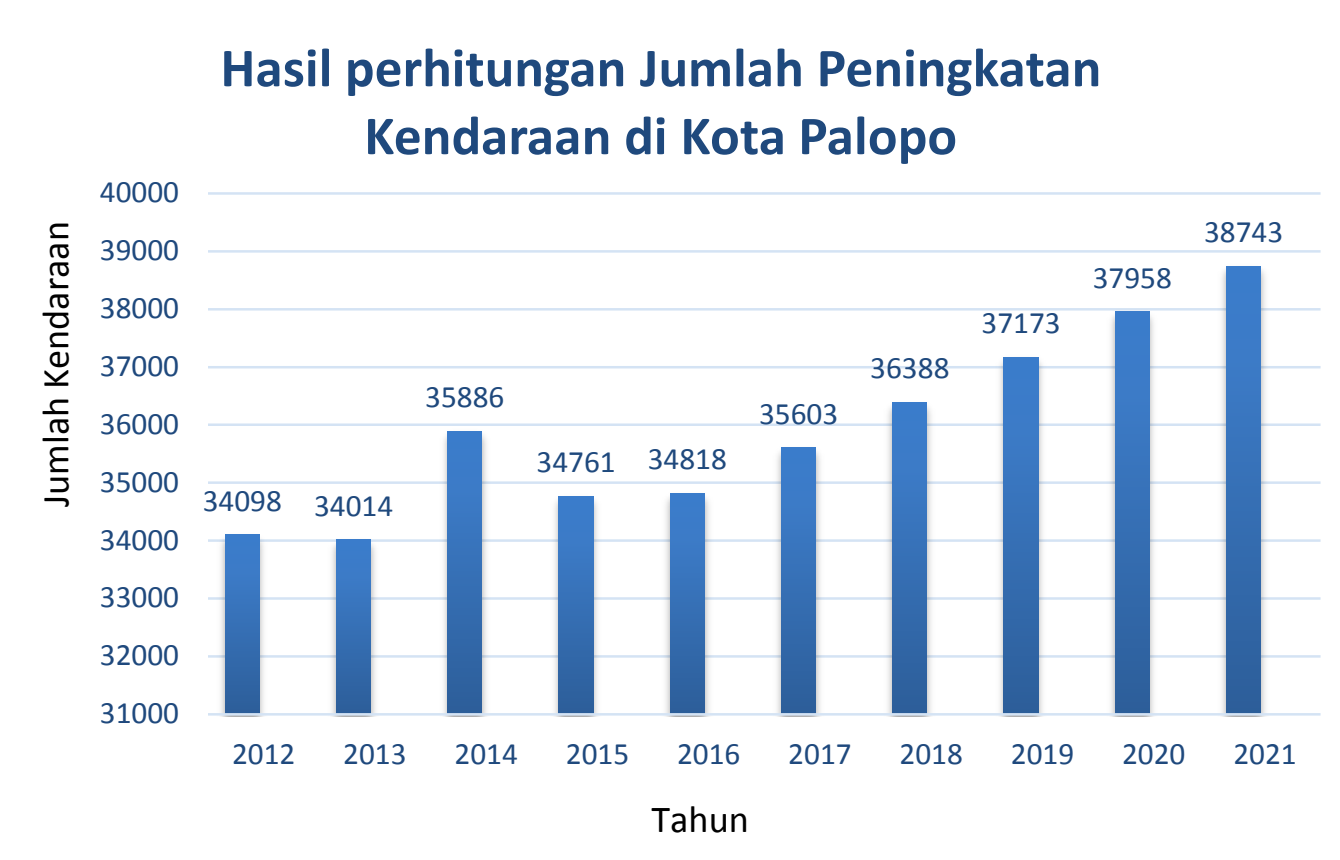

Gambar 4. Garafik Hasil Peramalan Dari Metode Aritmatik Untuk Jumlah Kendaraan di Kota Palopo.

Dari hasil analisa perhitungan dari data 2012 sampai dengan 2016 dapat diramalkan bahwa jumlah peningkatan kendaran yang ada di Kota Palopo 5 tahun kedepan sampai dengan tahun 2021 rata-rata peningkatan sebanyak 785 unit setiap tahunnya. Mencari nilai rata-rata jumlah kasus kecelakaan di kota palopo dapat dihitung dengan:

Dimana :

$$
r^{1}=P n-P o
$$

Pn = Jumlah kendaraan/jumlah kasus yang diproyeksikan tahun ke-n

Po $\quad=$ Jumlah kendaraan/jumlah kasus pada (awal tahun) tahun

$\mathrm{ke}-1$

$\mathrm{r}^{1}=$ Pertumbuhan kendaraan/jumlah kasus dalam 1 tahun Maka digunakan perhitungan:

$\mathrm{r}^{1}=$ Jumlah kendaraan/jumlah kasus pada tahun 2013 - jumlah penduduk pada tahun 2012

$\mathrm{r}^{1}=98-104$

$\mathrm{r}^{1} \quad=6$

Maka diperoleh hasil Perhitungan untuk rata-rata jumlah kendaraan tahun 2012 sampai dengan tahun 2016.

Tabel 5. Hasil perhitungan rata-rata jumlah kasus kecelakaan tiap tahun \& (\%)

\begin{tabular}{cccc}
\hline \hline Tahun & Jumlah Kasus Kecelakaan & $\mathbf{r}^{\prime}$ & Presentase (\%) \\
\hline 2012 & 98 & 6 & $5.8 \%$ \\
2013 & 104 & 124 & $54.4 \%$
\end{tabular}




\begin{tabular}{|c|c|c|c|}
\hline \multirow[t]{2}{*}{2014} & 228 & & \\
\hline & & 419 & $64.8 \%$ \\
\hline \multirow[t]{2}{*}{2015} & 647 & & \\
\hline & & 343 & $-112.8 \%$ \\
\hline \multirow[t]{2}{*}{2016} & 304 & & \\
\hline & Jumlah & 892 & \\
\hline
\end{tabular}

Sumber : Hasil Analisa

$$
\begin{aligned}
& r=\frac{\mathrm{Sr}^{1}}{\mathrm{n}} \\
& x=\frac{892}{4} \\
& r=223
\end{aligned}
$$

Perhitungan Metode Aritmatik untuk jumlah kendaraan rata-rata dengan menggunakan tahun 2016 adalah:

$$
\begin{aligned}
\text { Pn } & =P o+n \cdot r \\
& =304+(1 \times 223 \\
& =527
\end{aligned}
$$

Maka diperoleh hasil Perhitungan dengan metode aritmatik untuk jumlah kasus kecelakaan tiap tahunnya di Kota Palopo, dari tahun 2016 sampai dengan tahun 2021.

Tabel 6. Hasil Peramalan dari Perhitungan metode aritmatik untuk jumlah kasus Kecelakaan di kota palopo.

\begin{tabular}{ccccc}
\hline \hline No & Tahun & $\mathbf{r}^{\prime}$ & Pn & Presentase (\%) \\
\hline 1 & 2017 & 223 & 527 & $42.3 \%$ \\
2 & 2018 & 223 & 750 & $29.7 \%$ \\
3 & 2019 & 223 & 973 & $22.9 \%$ \\
4 & 2020 & 223 & 1196 & $18.6 \%$ \\
5 & 2021 & 223 & 1419 & $15.7 \%$ \\
\hline \hline
\end{tabular}

Sumber: Hasil Analisa

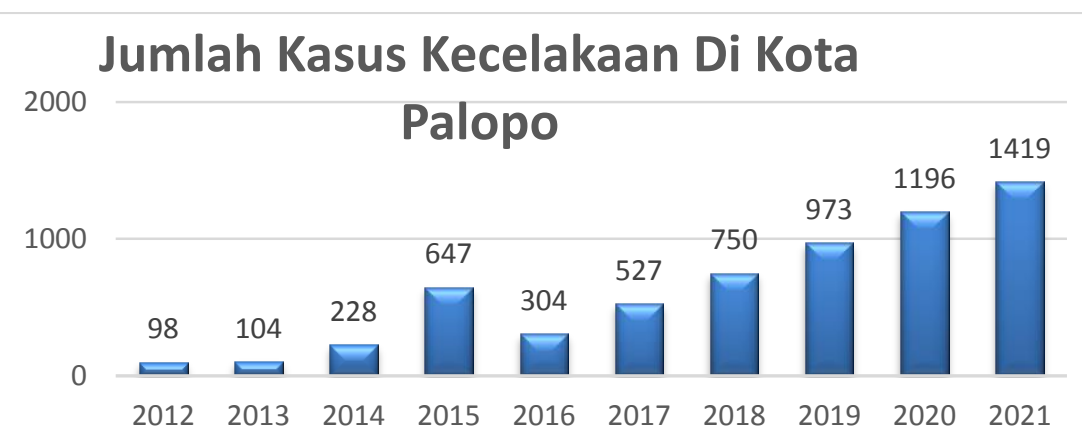

Gambar 5. Grafik Hasil Peramalan Dari Metode Aritmatik Untuk Jumlah Kasus

Kecelakaan di Kota Palopo. 
Dari hasil data analisa jumlah kasus kecelakaan dikota palopo dari tahun 2012 sampai dengan tahun 2016 dapat diramalkan 5 tahun kedepan rata-rata mengalami kenaikan sebanyak 223 kasus kecelakaan.

Korelasi antara pertumbuhan kendaraan bermotor terhadap tingkat kecelakaan lalu Lalu Lintas di Kota Palopo, dapat dilihat dari Grafik dibawah ini.

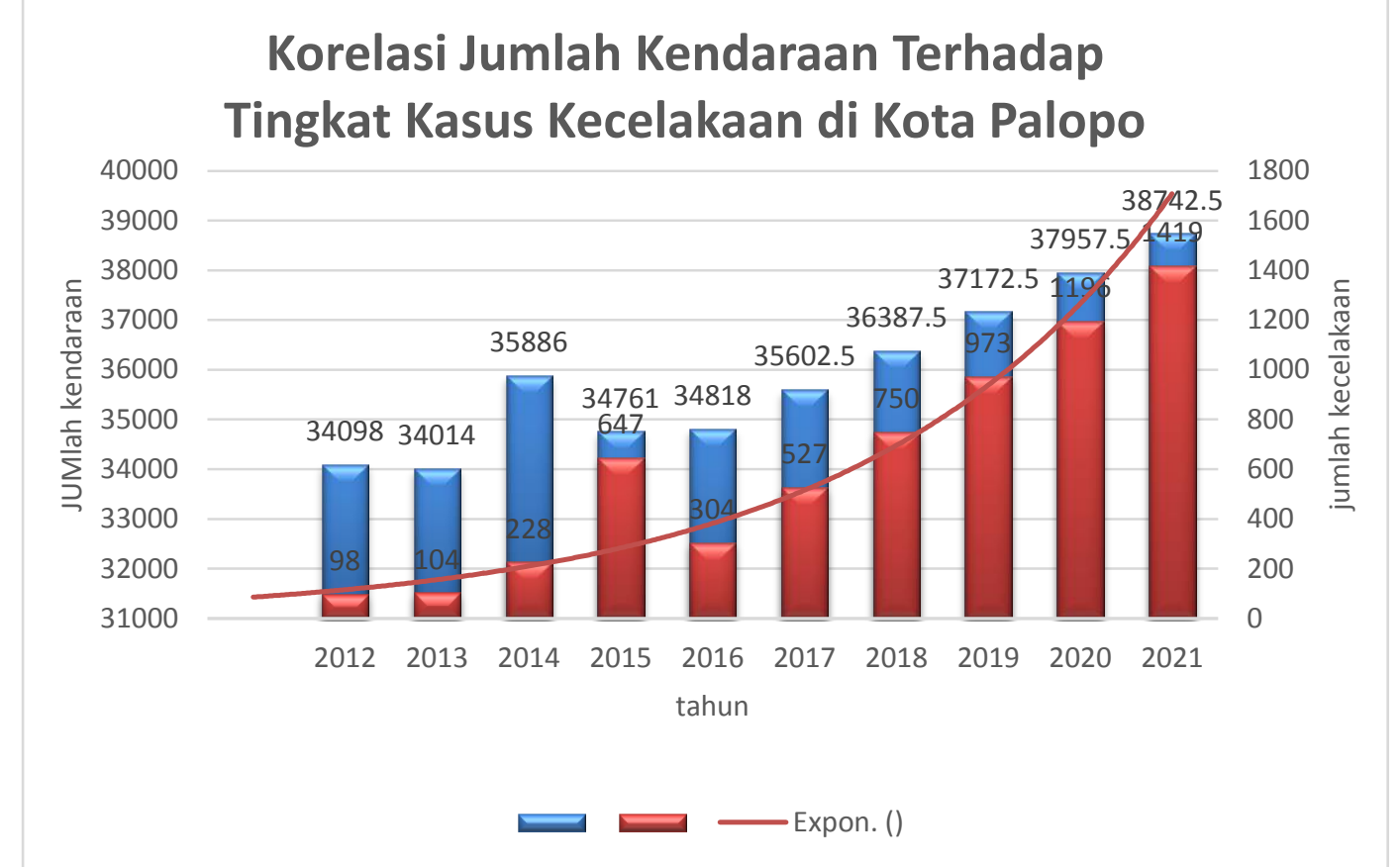

Gambar 6. Hasil Korelasi Peramalan Dari Metode Aritmatik Untuk Jumlah Kendaraan dan Jumlah Kasus Kecelakaan di Kota Palopo.

Dari hasil korelasi tingkat kendaraan bermotor dengan jumlah kasus kecelakaan di Kota Palopo. Jumlah kendaraan pada tahun 2012 adalah 34098 unit sedangkan tingkat kecelakaan 98 kasus, pada tahun 2013, jumlah kendaraan 34014 unit ini mengalami penurunan sedangkan tingkat kecelakaan meningkat 104 kasus, pada tahun 2014 jumlah kendaraan naik 35886 unit sedangkan jumlah kecalakaan naik pula 228 kasus, pada tahun 2015 jumlah kendaraan mengalami penurunan 34761 sedangkan jumlah kecelakaan mengalami peningkatan cukup seknifikan yaitu 647 kasus kecelakaan, pada tahun 2016 tingkat kendaraan naik 34818 unit sedangkan jumlah kecelakaan mengalami penurunan 304 kasus dibandingkan tingkat kecelakaan pada tahun 2015 sebanyak 647 kasus kecelakaan dan pada tahun 2017 sampai tahun 2021 pertumbuhan kendaraan dan tingkat kasus kecelakaan mengalami peningkatan dengan rata-rata, jumlah pertumbuhan kendaraan rata-rata sebanyak 785 unit dan tingkat jumlah kecelakaan rata-rata sebanyak 223 kasus.

Dari hasil gambar grafik di dapatkan hasil presentase (\%) dari jumlah pertumbuhan kendaraan dengan jumlah kasus kecelakaan mulai dari tahun 2012 sampai dengan tahun 2021 yang ada di Kota Palopo.

Tabel 7. Hasil Presentase dari Perhitungan metode aritmatik untuk jumlah kasus Kecelakaan di kota palopo.

\begin{tabular}{ccc}
\hline \hline Tahun & $\begin{array}{c}\text { Jumlah (\%) } \\
\text { Pertumbuhan Kendaraan }\end{array}$ & $\begin{array}{c}\text { Jumlah (\%) } \\
\text { Kasus Kecelakaan }\end{array}$ \\
\hline 2012 & $0 \%$ & $0 \%$
\end{tabular}




\begin{tabular}{lcc}
\hline & & \\
2013 & $-0.2 \%$ & $5.8 \%$ \\
2014 & $5.2 \%$ & $54.4 \%$ \\
2015 & $-3.2 \%$ & $64.8 \%$ \\
2016 & $0.2 \%$ & $-112.8 \%$ \\
2017 & $2.2 \%$ & $42.3 \%$ \\
2018 & $2.2 \%$ & $29.7 \%$ \\
2019 & $2.1 \%$ & $22.9 \%$ \\
2020 & $2.1 \%$ & $18.6 \%$ \\
2021 & $2.0 \%$ & $15.7 \%$ \\
\hline \hline
\end{tabular}

Sumber: Hasil Analisa

\section{KESIMPULAN}

Dari hasil analisis data dan pembahasan yang telah dilakukan menggunakan analisa metode Aritmatik, untuk mengetahui laju pertumbuhan kendaraan dan menentukan korelasi antara tingkat kasus kecelakaan yang ada di Kota Palopo serta menentukan tingkat presentase pertumbuhan kendaran dan tingkat kasus kecelakaan dalam tiap tahunnya, maka dapat disimpulkan bahwa :

1. Laju pertumbuhan kendaraan bermotor di Kota Palopo pada tahun 2021 sebesar $2.0 \%$. Peningkatan ini mengalami kenaikan setiap tahun dikarenakan semakin meningkatnya kebutuhan kepemilikan kendaraan bermotor.

2. Korelasi antara bertambahnya jumlah kendaraan di Kota Palopo, berdampak pada jumlah kasus kecelakaan yang terjadi, ini dapat di lihat dari hasil analisa gambar grafik korelasi antara tingkat pertumbuhan kendaraan dan tingkat kasus kecelakaan. Peningkatan jumlah kendaraan pada tahun 2017 adalah $2.2 \%$ sedangkan jumlah kecelakaan juga mengalami kenaikan sebesar $42.3 \%$.

\section{DAFTAR PUSTAKA}

Ditlantas Kepolisian Republik Indonesia 2007. Ibid

Djayoesman, H. S. 1976. Polisi dan Lalu Lintas. Bandung: Mabes Kepolisian Republik Indonesia Press

Djayoesman, H. S. 1976. Polisi dan Lalu Lintas. Bandung: Mabes Kepolisian Republik Indonesia Press

Fachrurrozy 2001. Keselamatan Lalu Lintas. Yogyakarta: Universitas Gadjah Mada Hobbs, 1995. Perencanaan dan tekni Lalu Lintas. Universitas Gadjah Mada

Marlok, Edward K. 1995 Pengantar Teknik dan Perencanaan Transportasi. Jakarta: Erlangga

Neuman, W. Lauwrence. 2003. Social Researh Methods: Qualitative and Quantitative Approaches, 5th edition. Boston: Pearson Education. Inc

Poerwodarminto, WJS. 1976. Kamus Besar Bahasa Indonesia. Jakarta: Balai Pustaka Pignataro, L.J. 1976. Traffic Engineering Thery and Practice. Englewood Cliffs, New Jersey: New York

Perundang-Undangan: Undang-Undang Nomor 14 Tahun 1992 Tentang Lalu Lintas dan Angkutan Jalan Undang-Undang Republik Indonesia Nomor 38 Tahun 2004 Tentang Jalan.s

: Nomor 22 Tahun 2009 Tentang Lalu Lintas dan Angkutan Jalan Undang-Undang Republik Indonesia 
Saiful Achmad, 2007. Fakulas Teknik : Makassar. Skripsi Penjualan kendaaraan Roda Dua terhdap tingkat kecelakaan

Salim, Abbas. 2006. Manajemen Transportasi. Jakarta: Rajawali Press

Soehartono, et al. 1990. Penanggulangan Kecelakaan di Jalan Tol Ditinjau dari Aspek Perencanaan dan Pengelolaan, Fourth Annual Conference on Road Engineering Directorat General of Highways. Departemen Pekerjaan Umum

TRL-UK/Institute of Road Engineering. 1997. Accident Costs in Indonesia. Road Reserch Development Project, Report No. RRDP 17. Bandung: Agency for Research and Development, Indonesia

Tamin, Ofyar Z. 2000. Perencanaan \& pemodelan transportasi / Ofyar Z. Tamin. Bandung : Penerbit ITB 